\title{
Institutional Investor Shareholdings and Corporate Social Responsibility - Evidence from Tourism Related Industries in China
}

\author{
Lei Zheng ${ }^{1, *}$, Xuemeng Guo ${ }^{1}$, Libin Zhao $^{2}$, and Yuting Feng ${ }^{1}$ \\ ${ }^{1}$ Beijing Jiaotong University, School of Economics and Management, 100044 Beijing, P.R. China \\ ${ }^{2}$ Wuhan Textile University, School of Accounting, 430073, P.R. China
}

\begin{abstract}
Using data from Chinese A-share listed companies in tourism related industries from 2009 to 2018 , this paper examines the influence of institutional investor shareholdings on corporate social responsibility (CSR) performance. Results show that: First, institutional investor shareholdings can significantly improve CSR performance of tourism related public companies in China. After implementing robustness test, this positive relationship remains solid. Second, the positive effect of institutional investor shareholdings is significantly unbalanced regarding different CSR dimensions, with the most salient influence in promoting companies' social welfare contributions. And third, the impact of institutional investor shareholdings can be strengthened when listed companies are ultimately controlled by the state.
\end{abstract}

\section{Introduction}

As an essential part of the national economy, tourism plays an important role in promoting the economic growth of a country or a region. According to the statistical data released by the Ministry of Culture and Tourism of the People's Republic of China, the comprehensive contribution of the tourism industry to the total GDP is 10.94 trillion yuan in 2019 , accounting for $11.05 \%$ of the total GDP, with an increase of $11 \%$ to the data in the former year. However, behind the high-speed development, tourism companies' unethical behaviors, such as putting unreasonable profit pressures on their employees and forcing tourists pay higher premiums to ordinary goods, are frequently revealed and cause consumers' distrust to the whole tourism industry. As required by the "Tourism Law" in 2013, Chinese tourism companies should actively engage in CSR related activities to achieve the sustainable growth of the whole tourism industry.

Although companies' CSR investment decisions can be highly depended on the personal characters of their top-tier managers [1], sophisticated institutional investors' role in taking part in corporate governance and acting as financial investors can also cause significant impacts on firms' CSR activities. Using archival data in 41 countries around the world, Dyck et al. provide empirical evidence on the positive connection between institutional investor shareholdings and firms' CSR performance, suggesting that institutional investors are motivated by both financial and social returns in promoting firms' CSR performance [2].
Although the positive relationship has been proved on an international scale, little evidence of its suitability on a specific country or one individual industry is given. Considering the unique profit-driven operating logics and lower level of government regulations in Chinese tourism related industries, it is still meaningful to examine the effect of institutional investor shareholdings on firms' CSR performance.

Empirical evidence of this paper shows that, institutional investors do have positive effects in promoting Chinese tourism related companies' CSR performance and this effect is most significant in the social welfare dimension of CSR activities. Besides, compared with Chinese non-SOEs in the tourism industry, SOEs are the major participants in CSR activities during the sample period. Overall, from the perspective of CSR in tourism related industries, this paper provides a closer look at the connection between Chinese capital market and the real economy, offering policy suggestions to promote the development of both tourism related public companies and the industry itself in China.

The remaining parts of this paper are organized as follows: part 2 reviews related literatures and offers hypotheses, part 3 introduces the research design, empirical results are presented in part 4 and part 5 provides conclusions.

\section{Literature review and hypotheses development}

Current literatures provide two opposite perspectives on the reason why firms invest in CSR related activities, namely the agency theory perspective and the stakeholder 
theory perspective, in explaining companies' investment decisions to benefit a lager set of stakeholders than merely maximize the value of their shareholders.

Proponents of the agency theory perspective believe that engaging in CSR related activities means that managers are transferring shareholders' wealth to other types of stakeholders who do not directly promote companies' financial performance. Thus, doing well in CSR related activities is a clear reflection of severe agency problems inside the company, causing damages to both the shareholder value and the firm value [3]. For example, managers may use charitable donations to pursue their private interests at the expense of shareholders' benefits [4].

However, under the perspective of stakeholder theory, it is not a zero-sum game to simultaneously achieve companies' operating success and social welfare [5]. By doing well in CSR related activities, companies can better communicate with their non-investing stakeholders to mitigate the information asymmetry problem and gather reputational capitals in both the capital market and the consumer market [6]. Further, reputational capitals brought by CSR activities can be regarded as "insurancelike" protections to prevent firm value decreasing in future adverse events [7].

Considering two motivations of CSR activities, institutional investors' roles of external monitors and financial investors may cause opposite influences on firms' CSR investment decisions. On the one hand, if managers tend to use CSR activities to cover their misbehaviours in seizing personal interests, then through directly participating in corporate governance producers, sophisticated institutional investors can constrain managers' discretionary CSR spending and thus hinder CSR performance of public tourism related companies in China. On the contrary, as point out by Chen et al. [8], individual investors do consider firms' CSR performance in choosing their investment portfolios. As professional financial investors, institutional investors have incentives to enlarge their asset pools and secure their investment profits. Under this circumstance, institutional investors can improve listed companies' CSR performance to put "insurance-like" protections on their investment targets and absorb social escrow funds. Based on the analysis above, we give the following hypotheses:

H1: Institutional investor shareholdings have negative effects on the CSR performance of Chinese tourism related public companies.

H2: Institutional investor shareholdings have positive effects on the CSR performance of Chinese tourism related public companies.

\section{Research design}

The following Model (1) is constructed to test the hypothesis $\mathrm{H} 1$ and $\mathrm{H} 2$. Because the influence of capital market activities on firms' CSR performance could show up with some lags [9-10], we use CSR scores in year $\mathrm{t}+1$ and other firm-level variables in year $\mathrm{t}$ in the model.

$$
C S R_{i, t+1}=\alpha_{0}+\alpha_{1} \text { Insh }_{i, t}+\sum \alpha_{k} \text { Controls }+ \text { Year }_{t}+\text { Ind }_{j}+\varepsilon(1)
$$

The variable CSR represents tourism related public firms' annual CSR performance ranked comprehensively and objectively by the professional third party, Hexun website (www.hexun.com). Using information from the listed company's annual financial report and CSR report, Hexun's CSR score provides a relatively exhaustive measure with few biases. A higher annual CSR score means a better CSR performance. The variable Insh is the independent variable, measured by a company's annual total institutional investors' shareholding ratio. Control variables are chosen following Adhikari [9] and are shown in Table 1. Year and industry fixed effects are also controlled in the regression model.

As illustrated above, listed firms' CSR scores are collected from Hexun website and all other firm level variables are gathered from CSMAR database. Following data processing procedures are implemented: first, firmyear observations with missing data are excluded from the regression sample; second, if a firm is special treated in some year, then its observation in that year is excluded; and third, all continuous variables are winsorized at $1 \%$ and $99 \%$ level to preclude influences of extreme values. The final sample consists of 283 firm-year observations. To ensure the robustness of the baseline results, we use robust standard error clustered at firm level in all regression processes.

Table1. Definition of variables

\begin{tabular}{|c|c|}
\hline Variable & Definition \\
\hline CSR & Annual CSR performance of listed companies \\
\hline Insh & Shareholding ratio of institutional investors \\
\hline Size & Natural logarithm of firm's year-end total assets \\
\hline ROA & Return on assets \\
\hline Cash & $\begin{array}{l}\text { The proportion of cash and cash equivalents to total } \\
\text { assets }\end{array}$ \\
\hline Lev & Debt-to-asset ratio \\
\hline Tax & Firm's effective tax rate \\
\hline MB & Market-to-book ratio \\
\hline $\mathrm{R} \& \mathrm{D}$ & Annual R\&D expense divided by total revenue \\
\hline Age & Firm age since it went public \\
\hline Dual & $\begin{array}{l}\text { Equals } 1 \text { if the CEO and the board chairman is the } \\
\text { same person, and } 0 \text { otherwise }\end{array}$ \\
\hline Toph & Shareholding ratio of firm's largest shareholder \\
\hline Year & Year dummy \\
\hline Ind & Industry dummy \\
\hline
\end{tabular}

\section{Empirical results}

\subsection{Descriptive statistics}

Table 2 provides the descriptive statistics of the full sample. The average CSR performance score in Chinese tourism related public companies in the sample period is around 25.63, with the minimum score of -4.03 and the maximum score of 74.90 , suggesting the large difference of CSR performance among listed companies. The mean and the standard deviation of institutional investor shareholdings are $6.64 \%$ and $6.50 \%$ respectively. The average ROA in the regression sample is about $5 \%$ and companies hold $22 \%$ of cash and cash equivalents to their total assets in average. The largest debt-to-asset ratio is near $90 \%$ and the highest market-to-book ratio is around 
11.71. All other controls variables are in reasonable ranges.

Table2. Descriptive statistics

\begin{tabular}{|c|c|c|c|c|c|c|}
\hline Variable & N & Mean & SD & Min & Median & Max \\
\hline CSR & 283 & 25.63 & 15.18 & -4.03 & 24.30 & 74.90 \\
\hline Insh & 283 & 6.64 & 6.50 & 0.03 & 4.35 & 25.84 \\
\hline Size & 283 & 22.09 & 1.28 & 19.77 & 22.13 & 25.92 \\
\hline ROA & 283 & 0.05 & 0.05 & -0.14 & 0.04 & 0.21 \\
\hline Cash & 283 & 0.20 & 0.16 & 0.02 & 0.15 & 0.72 \\
\hline Lev & 283 & 0.45 & 0.20 & 0.05 & 0.43 & 0.89 \\
\hline Tax & 283 & 0.22 & 0.14 & -0.43 & 0.23 & 0.79 \\
\hline MB & 283 & 2.87 & 2.07 & 0.93 & 2.24 & 11.71 \\
\hline R\&D & 283 & 0.47 & 1.62 & 0.00 & 0.00 & 16.23 \\
\hline Age & 283 & 10.78 & 6.94 & 0.00 & 12.00 & 24.00 \\
\hline Dual & 283 & 0.22 & 0.42 & 0.00 & 0.00 & 1.00 \\
\hline Toph & 283 & 37.37 & 16.09 & 8.93 & 36.99 & 75.09 \\
\hline
\end{tabular}

\subsection{Baseline regression results}

Panel A of Table 3 provides the baseline regression results using the full sample. The regression coefficient of the variable Insh is 0.50 and is statistically significant at $1 \%$ level, suggesting that every $1 \%$ increase in the institutional investor shareholding ratio will make Chinese tourism related public companies' CSR total score increase by 0.5 in average. Besides, companies with larger total assets and higher return on assets are more active in engaging in CSR related activities.

Table3. Baseline regression results and robustness test

\begin{tabular}{|c|c|c|}
\hline & $\begin{array}{l}\text { Panel A: } \\
\text { Baseline } \\
\text { regression }\end{array}$ & $\begin{array}{l}\text { Panel B: 2SLS using } \\
\text { instrumental variable }\end{array}$ \\
\hline Var & $\mathbf{C S R}_{\mathbf{t + 1}}$ & $\mathbf{C S R}_{\mathbf{t + 1}}$ \\
\hline \multirow[t]{2}{*}{ Insh } & $0.50 * * *$ & $1.19 * * *$ \\
\hline & $(2.78)$ & $(3.48)$ \\
\hline \multirow[t]{2}{*}{ Size } & $4.31 * * *$ & 2.71 \\
\hline & $(2.78)$ & (1.49) \\
\hline \multirow[t]{2}{*}{$R O A$} & $79.40^{* * * *}$ & 48.40 \\
\hline & $(3.42)$ & (1.41) \\
\hline \multirow[t]{2}{*}{ Cash } & -5.39 & -3.15 \\
\hline & $(-1.05)$ & $(-0.49)$ \\
\hline \multirow[t]{2}{*}{ Lev } & -14.48 & -14.39 \\
\hline & $(-1.61)$ & $(-1.40)$ \\
\hline \multirow[t]{2}{*}{$\operatorname{Tax}$} & 7.14 & $\begin{array}{c}1.73 \\
(0.17)\end{array}$ \\
\hline & $(0.82)$ & $(0.17)$ \\
\hline \multirow[t]{2}{*}{$M B$} & -0.47 & \multirow{2}{*}{$\frac{-1.05}{(-1.34)}$} \\
\hline & $(-0.83)$ & \\
\hline \multirow[t]{2}{*}{$R \& D$} & -0.35 & 0.30 \\
\hline & $(-0.96)$ & $(0.62)$ \\
\hline \multirow[t]{2}{*}{ Age } & -0.17 & -0.16 \\
\hline & $(-0.73)$ & $(-0.54)$ \\
\hline \multirow[t]{2}{*}{ Dual } & -2.48 & -0.41 \\
\hline & $(-1.01)$ & $(-0.12)$ \\
\hline \multirow[t]{2}{*}{ Toph } & 0.01 & $0.15^{*}$ \\
\hline & $(0.09)$ & $(1.68)$ \\
\hline Cons & $-63.79 * *$ & -35.61 \\
\hline & $(-2.18)$ & $(-1.04)$ \\
\hline Ind \& Year & Yes & Yes \\
\hline $\mathrm{N}$ & 283 & 199 \\
\hline Adj. $\mathrm{R}^{2}$ & 0.35 & 0.28 \\
\hline Coefficient of & e first stage & \begin{tabular}{l|l} 
& $0.71 * * *$
\end{tabular} \\
\hline res & & (11.48) \\
\hline
\end{tabular}

$* * *, * *, *$ represent $1 \%, 5 \%$ and $10 \%$ level of significance respectively (two-tails). T-values are presented beneath the coefficient estimates in parentheses.

\subsection{Robustness test}

Considering that the baseline regression results can be influenced by the endogeneity problem, such as the reverse causality and omitted variables in the initial research design, we follow Erhemjamts and Huang [10] and use lagged institutional investor shareholding ratio as the instrumental variable to implement 2SLS regression. The 2SLS regression results are presented in Panel B of Table 3. In the first stage regression, the coefficient of the instrumental variable $\mathrm{Insh}_{\mathrm{t}-1}$ is significantly positive at $1 \%$ level, suggesting that the instrumental variable is not weak in predicting the variable Insh. When using the predicted institutional investor shareholding ratio as the independent variable in the second stage, the regression coefficient is 1.19 and is still statistically significant at $1 \%$ level, suggesting that the baseline results are robust.

Overall, both the baseline and the 2SLS results support the hypothesis $\mathrm{H} 2$, illustrating that institutional investor shareholdings can effectively promote Chinese public firms' CSR performance in tourism related industries.

\subsection{Additional analysis}

\subsubsection{Separate CSR dimensions}

According to Hexun's CSR rating standards, five separate dimensions are included in the CSR ranking category, namely the responsibility to shareholders (Sha), to employees (Emp), to suppliers, customers and consumers (SCC), to the natural environment (Env) and to the social welfare (Soc). Every company' CSR total score is calculated by summing up each score in these five dimensions.

To be more specific, Sha score mainly measures indicators such as companies' profitability, solvency, innovation capability and received punishments from regulators. Emp score mainly focuses on companies' investment in employee education and employee benefits. SCC measures corporate responsibility to supplier, customers and consumers, mainly focusing on product quality, business honesty and the quality of after-sale service. Companies' environment friendly investment activities are reflected in the Env score and activities in promoting social welfare, such as tax-paying and charitable donations, are measured in the Soc score.

Using detailed CSR data, we further examine the effects of institutional investor shareholdings on separate CSR dimensions. Table 4 below presents the regression results. It is clear that institutional investor shareholding has the most powerful influence on CSR performance of Chinese public tourism related companies in their responsibility to the society, while having the least and insignificant effect on the responsibility to employees. Results from Table 4 illustrate that Chinese institutional investors need to put more attention on tourism related firms' responsibilities to shareholders, to employees and to the natural environment when promoting firms' overall CSR performance. 
Table4. Influences on separate CSR dimensions

\begin{tabular}{|c|c|c|c|c|c|}
\hline Var & Sha & Emp & $\mathrm{SCC}$ & Env & Soc \\
\hline Insh & 0.09 & 0.03 & $0.14 * *$ & $0.07 *$ & $0.17 * * *$ \\
\hline & $(1.46)$ & $(1.06)$ & $(2.06)$ & $(1.74)$ & (3.99) \\
\hline $\begin{array}{c}\text { Controls \& } \\
\text { Constant }\end{array}$ & Yes & Yes & Yes & Yes & Yes \\
\hline Ind \& Year & Yes & Yes & Yes & Yes & Yes \\
\hline $\mathrm{N}$ & 283 & 283 & 283 & 283 & 283 \\
\hline Adj. $\mathrm{R}^{2}$ & 0.50 & 0.26 & 0.18 & 0.17 & 0.25 \\
\hline
\end{tabular}

\subsubsection{Difference between SOEs and Non-SOEs}

Compared with non-state-owned enterprises (Non-SOEs), state-owned enterprises (SOEs) still paly a basic and essential role in sustaining the high-speed economic growth in China [11]. Considering the differences in operating logics and evaluation mechanisms between SOEs and Non-SOEs, it is important to further examine the role of company's equity nature in moderating the relationship between institutional investor shareholdings and listed firms' CSR performance.

In practices, managers of SOEs are supervised and evaluated by the State-owned Assets Supervision and Administration Commission of the State Council (SASAC). In the evaluation processes, SASAC tends to give companies that take higher level of social responsibilities more favourable evaluations [12]. Given that managers in SOEs are quasi-government officers, they are more likely to follow evaluation standards set by SASAC to get political promotions than merely improving financial performance to get higher monetary compensations [11]. In addition, the fact that Chinese financial sector is controlled by the government makes SOEs easier to obtain external financial resources [13], further enabling managers to engage in CSR activities at lower costs. Therefore, compared with managers in nonSOEs, SOE managers have more incentives and capabilities to engage in CSR related activities when institutional investors propose them to do so. It is thus predicted that the positive effect of institutional investor shareholdings should be more salient in the SOE group than in the non-SOE group. And results from Table 5 confirm our prediction concerning the moderating effect of company's equity nature.

Table5. Moderating effect of company' ultimate ownership

\begin{tabular}{|c|c|c|}
\hline & SOEs & Non-SOEs \\
\hline Var & CSR & CSR \\
\hline Insh & $0.53^{* *}$ & 0.10 \\
\hline & $(2.20)$ & $(0.38)$ \\
\hline $\begin{array}{c}\text { Controls \& } \\
\text { Constant }\end{array}$ & Yes & Yes \\
\hline Ind \& Year & Yes & Yes \\
\hline $\mathrm{N}$ & 162 & 121 \\
\hline Adj. $\mathrm{R}^{2}$ & 0.37 & 0.34 \\
\hline
\end{tabular}

$* * *, * *, *$ represent $1 \%, 5 \%$ and $10 \%$ level of significance respectively (two-tails). T-values are presented beneath the coefficient estimates in parentheses.

\section{Conclusions}

This paper examines the relationship between institutional investor shareholdings and public companies' CSR performance in Chinese tourism related industries. Empirical results show that, institutional investors can generally promote tourism companies' CSR performance. While this positive influence is not statistically significant in shareholder responsibility and employee responsibility, institutional investors can effectively improve companies' responsibilities to the stakeholders in the supply chain, to the natural environment and to social welfare.

According to the empirical results, we suggest that institutional investors should be more active in promoting tourism related companies' CSR activities regarding shareholder responsibility and employee responsibility, and should put more efforts in improving Chinese nonSOEs in tourism related industries to engage in CSR activities.

\section{Acknowledgement}

This paper is supported by the research programs of National Natural Science Foundation of China (71973009, $71402130)$ and the research program of National Social Science Fund of China (19CJY006).

\section{References}

1. H. Cronqvist, F. Yu. J. Financ. Econ. 126(3), 543-562 (2019)

2. A. Dyck, K.V. Lins, L. Roth, H.F. Wagner. J. Financ. Econ. 131(3), 693-714 (2019)

3. R. Borghesi, J.F. Houston, A. Naranjo. J. Corp. Financ. 26, 164-181 (2014)

4. R.W. Masulis, S.W. Reza. Rev. Financ. Stud. 28(2), 592-636 (2015)

5. M. Porter, M.R. Kramer. Harv. Bus. Rev. 89(1-2), 62-77 (2011)

6. C. Flammer. Manage. Sci. 61(11), 2549-2568 (2015)

7. D. Minor, J. Morgan. Calif. Manage. Rev. 53(3), 4059 (2011)

8. T. Chen, H. Dong, C. Lin. Financ. Econ. 135(2), 483504 (2020)

9. B. Adhikari. J. Corp. Financ. 41, 201-216 (2016)

10. O. Erhemjamts, K. Huang. J. Bus. Res. 105, 61-79 (2019)

11. Xin Q., Bao A., and Hu F. China J. Account. Res. 12(2), 177-189 (2019)

12. F. Du, G. Tang, S.M. Young. Account. Rev. 87(5), 1555-1588 (2012)

13. K. J. Lin, X. Lu, J. Zhang, Y. Zheng. China J. Account. Res. 13(1), 31-55 (2020) 